\title{
日常生活環境における大腿義足歩行の主要な下肢関節回転運動パターンの解析
}

\section{Analysis of principal rotational motion pattern of lower limb joints during trans-femoral prosthetic gait in daily living environment} \\ Yuichiro HAYASHI ${ }^{* 1}$, Nobutaka TSUJIUCHI ${ }^{* 2}$, Ryuji UNO*3, \\ Yuta MAKINO*3, Yasushi MATSUDA ${ }^{* 4}$ and Youtaro TSUCHIYA* ${ }^{* 5}$ \\ ${ }^{* 1}$ Department of Mechanical Engineering, Graduate School of Science and Engineering, Tokyo Metropolitan University \\ 1-1 Minami-Osawa, Hachioji-shi, Tokyo 192-0397, Japan \\ ${ }^{* 2, * 3}$ Department of Mechanical Engineering, Graduate School of Science and Engineering, Doshisha University \\ 1-3 Miyakodani, Tatara, Kyotanabe-shi, Kyoto 610-0394, Japan \\ ${ }^{* 4}$ Kawamura-Gishi Co., LTD. \\ 1-12-1 Goryo, Daitoh-shi, Osaka 574-0064, Japan \\ ${ }^{*}$ Tec-Gihan Co., LTD. \\ 1-22 Nishinohata, Okubo-cho, Uji-shi, Kyoto 611-0033, Japan
}

林 祐一郎 ${ }^{* 1}$, 辻内 伸好 ${ }^{* 2}$, 宇野 龍司 ${ }^{* 3}$ 牧野 裕太 ${ }^{* 3}$, 松田 靖史 ${ }^{* 4}$ ，土屋 陽太郎 ${ }^{* 5}$

\section{Received 26 September 2015}

\begin{abstract}
Recently, it is thought that trans-femoral amputees are needed to regain moving pattern by refined rehabilitation program using joint angle and joint moment as kinematic and kinetic conditions on the prosthetic limb with the artificial knee joint. On the other hand, understanding physical feature quantities applied on the prosthetic limb is important for biomechanical consideration of trans-femoral amputees. However, the proposed evaluation method by using singular value decomposition of each joint moment during trans-femoral prosthetic gait has not yet been considered. Besides, when the proposed evaluation method of each joint moment is applied to trans-femoral prosthetic gait, the gait measurement has been experimented concerning only the constrained unnatural gait by laboratory, practical gait as the activities of daily living has not adequately been experimented. In this paper, analysis of principal rotational motion pattern of lower limb joints concerning joint angles and joint moments during trans-femoral prosthetic gait based on the focus on level, upslopes, downslopes, upstairs and downstairs as daily living environment is aimed to clarify comprehensive spatial coordination patterns of a trans-femoral amputee with the prosthetic limb. Each physical parameter is measured by using mobile force plate and attitude sensor. As a result of the experiments and data analysis, singular value decomposition extracts the principal motion patterns from the physical feature quantities and specific points of accurate differences between gait conditions are elucidated. In the end, the effectiveness of biomechanical evaluation of each trans-femoral prosthetic gait pattern by the proposed method is validated.
\end{abstract}

Key words : Biomechanics, Gait analysis, Trans-femoral prosthetic gait, Singular value decomposition, Joint angle, Joint moment, Mobile force plate, Attitude sensor, Activities of daily living

\section{1. 緒言}

近年，疾病や労働災害・交通事故による下肢切断などの歩行障害を有する患者が増加しており，高齢化社会の 到来と相まってリハビリテーション医療の重要性が高まってきている(江原, 山本, 2001; 江原, 山本, 2002; 北 村他， 2007; 豊田他，2008; 林他，2011). 現在，日本国内における下肢切断者はおよそ六万人存在し，そのため

No. 15-00525 [DOI: 10.1299/transjsme.15-00525], J-STAGE Advance Publication date : 2 February, 2016

${ }^{* 1}$ 正員, 首都大学東京大学院 理工学研究科 機械工学専攻 (厂192-0397 東京都八王子市南大沢 1-1)

*2 正員, フェロー, 同志社大学 理工学部 機械システム工学科（テ610-0394 京都府京田辺市多々羅都谷 1-3）

*3 同志社大学大学院 理工学研究科 機械工学専攻

*4 川村義肢（株）（干574-0064 大阪府大東市御領 1-12-1）

*5 （株）テック技販（广611-0033 京都府宇治市大久保町西ノ端 1-22）

E-mail of corresponding author: hayashiy@tmu.ac.jp 
義足の必要性が大きくなっている(川村，2004; 伊藤，赤居，2008). 中でも，そのうち二万人以上を占めるといわ れている大腿切断者(沢村，2004)の義足歩行においては膝継手を失った膝関節の代替としており，日常生活動作 において立脚期中に生じやすい膝折れや遊脚期の振り出しに関して多くの不安定な歩容を生じるなどの問題があ る。したがって，大腿義足装着者の一歩行周期中に生じる関節角度や関節モーメントといった物理量を算出し定 量的な評価指標とみなすことにより, 膝継手に求められる各機能が満たされているかどうかの程度を判断できる とともに，義足歩行訓練によるリハビリテーション方法の改善が可能と考えられる(鈴木，2004; 鈴木，2009).

これまでに，ヒトの運動中に生じる関節角度，関節モーメントなどを算出し，それらの時間変化を各関節につ いて整理した上，観測行列と呼ばれる評価指標を表す行列にまとめ，特異值分解を施すことによって，主要な関 節間協調およびその活動パターンを求める定量的評価手法が提案され, 歩行など種々の運動に適用されている(舩 戸他，2010；林他，2015a). しかし，大腿義足歩行の計測と解析に関する先行研究において，このような手法は 関節角度のみにしか適用されておらず(林他，2015a), 動力学的な決定因子と定義され非常に有用な力覚情報であ る下肢の各関節モーメントを運動要素に含めていないため, 歩行中の関節周りにおける回転運動の構成原理が未 解明であると考えられる. 加えて, その場合において義足歩行計測に使用した実験装置は据え置き型の三次元動 作解析装置であり, 使用場所や歩数の制約が大きく日常生活環境における実際的な歩行を実現しているといえず, ウェアラブルな計測装置を用いた制約のない歩行運動の計測に基づく特徴量による定量的な解析が必要である.

そこで，本研究では，平地に加えて斜面および階段といった日常生活環境における大腿義足歩行の基礎的なメ カニズムを客観的な指標としての各物理量の働く方向を表す主成分べクトルに基づいて評価するため, 歩行中の 下肢関節回転運動におけるパターンを表すと考えられる関節角度・モーメントについて主成分分析によって特徵 を抽出し, 一般的な大腿義足歩行における運動の自由度からみた原理的な特徵量を指標として獲得することを目 的とする. 最初に, サンダル型の移動式床反力計と加速度センサ, ジャイロセンサ, 地磁気センサを内蔵した姿 勢センサを用いたウェアラブルな歩行解析システム(林他，2013)を適用し，平地・斜面および階段の上り下りの 計 5 種類の条件下における大腿義足歩行を計測する. 次に, それらより算出した各関節角度および関節モーメン トの時系列挙動から構成される観測行列に関して特異值分解を施し, 歩行運動全体に関する各物理量に対応した 主成分の解析をおこない, 日常生活動作を反映した大腿義足歩行における運動学・動力学的に主要と考えられる 動作パターンを抽出する. 最終的には, これまでの提案手法の適用例(林他, 2015b)と同様に各環境条件において 生じた主要な運動パターンの相互比較・考察をおこない, 大腿義足歩行に対しての解析手法の有効性を検証する.

\section{2. 実験方法}

\section{$2 \cdot 1$ 被験者および大腿義足}

本研究では, 20 年以上に渡って一般的なソケット型大腿義足を装着している男性の右脚大腿切断者 1 名を被験 者とした．被験者を 1 名とした理由としては，代表的な大腿義足として最も一般的に流通しているソケット型を 装着している被験者を採用することにより，基本的な大腿義足装着者の歩行特性を評価可能であると考えたこと とする. 被験者に関する身体特性の詳細な情報を表 1 に示す. ここで, 全体重は大腿切断者の体重と義足の重量 の和とする. 歩行計測実験は同志社大学京田辺校地にて実施し, 全体的な作業については臨床実験に関する同志 社大学研究倫理委員会の承認を得るとともに, あらかじめ被験者に十分な説明を与え, 同意を得たものとした. また, 計測前に歩行訓練を実施し, 装着した大腿義足の機能を十分に発揮した歩行を可能として計測を開始した.

大腿義足における部位の中でも中心的な役割を果た寸膝継手については，大腿義足装着者において多くの場合 に用いられている図 1 に示寸体重を利用したブレーキによって立脚期の膝折れを防止する荷重ブレーキ式膝継手 である Ossur 社製 Total Knee 2100 を採用した。 これは，立脚期前期において健常者と同様に最大 15 [deg] まで抵 抗を伴う軽度屈曲が発生し踵接地時の衝撃を吸収する上, 独自の幾何学的ロックシステムを用いた多軸リンク機 構および膝軸周りに組み合わされた特殊なゴムバンパーにより, 軽度屈曲時に膝折れを防止可能とするバウンシ ングと呼ばれる立脚期制御機能を有する.

\section{$2 \cdot 2$ 実験装置}

使用する実験装置として, テック技販社製のウェアラブルな歩行解析システム全体の概略図を図 2 に示す. 本 システムは, 図 3 に示すような片脚に 2 基ずつ合計 4 基の小型床反力計を靴底に組み込んだサンダル型の移動式 
床反力計 1 足分に加えて, 片脚について 3 基ずつ組み込んだ合計 6 基の姿勢センサおよびデータロガによって構 成される. 小型床反力計, 姿勢センサならびにデータロガはいずれも比較的軽量かつ装着者への負担が少なく, 使用しや寸いものとなっている. 姿勢センサには STM 社製 3 軸加速度センサ LIS331DLH, STM 社製 2 軸ジャイ ロセンサ LPR530AL および STM 社製 1 軸ジャイロセンサ LY530ALH から構成される 3 軸ジャイロセンサ, Honeywell 社製 3 軸地磁気センサ HMC5843 が内蔵されており，大腿部，下腿部，腰部，背部に装着することによ って下肢および体幹の運動学情報を計測する. 各種センサの仕様を表 2 に示す. 小型床反力計には, 姿勢センサ と同様に加速度センサ, ジャイロセンサ，地磁気センサが内蔵されており, 足の運動学情報を計測する. 移動式 床反力計および姿勢センサの計測データはデータロガを介して無線 LAN により PC に転送・記録され，それら を演算することにより歩行運動時の床反力および下肢の姿勢を表す関節角度, 関節モーメントを算出可能である.

\section{$2 \cdot 3$ 実験条件}

表 3 および図 4〜図 6 に示寸特別に環境が整った実験室以外の代表的なヒトの歩行路環境である平地における 直進，斜面および階段の昇降といった合計 5 種類の歩行条件下において, 図 7 に示すように歩行解析システム一 式を装着した被験者が自由な速度で 10 歩以上の歩行をおこなった際の計測データを取得した. また, 歩行解析シ ステムに組み込んだセンサについて設定した実験条件として，センサの各 ch におけるサンプリング周波数を 100 [Hz]とするとともに，ローパスフィルタのカットオフ周波数を $10[\mathrm{~Hz}]$ とした．さらに，斜面および階段の歩行条 件として, 表 3 のように斜面の傾斜角度を 5 [deg], 階段での段差高さを 0.175 [m], 段差奥行きを 0.3 [m] とした.

Table 1 Subject characteristics. He has worn the trans-femoral prosthesis of normal socket-type for at least 29 years.

\begin{tabular}{c|c}
\hline \hline Gender (Male/Female) & Male \\
\hline Age (Years) & 31 \\
\hline Height [m] & $1.70[\mathrm{~m}]$ \\
\hline Total Mass [kg] & $73.0[\mathrm{~kg}]$ \\
\hline Side of Amputation (Right/Left) & Right \\
\hline Footwear & Running Shoes \\
\hline Prosthetic Foot & Vari-Flex \\
\hline Prosthetic Knee & Total Knee 2100 \\
\hline
\end{tabular}

Table 3 Descriptions of the five various activities. Walking is going straight all.

\begin{tabular}{c|c}
\hline \hline Activities & Descriptions \\
\hline Level Walking & Level walking along a level, straight-line walkway \\
\hline Upslope & Ascending $5[\mathrm{deg}]$ of a slope \\
\hline Downslope & Descending $5[\mathrm{deg}]$ of a slope \\
\hline Upstairs & Ascending stairs of $0.175[\mathrm{~m}]$ height $\times 0.3[\mathrm{~m}]$ deep \\
\hline Downstairs & Descending stairs of $0.175[\mathrm{~m}]$ height $\times 0.3[\mathrm{~m}]$ deep \\
\hline
\end{tabular}

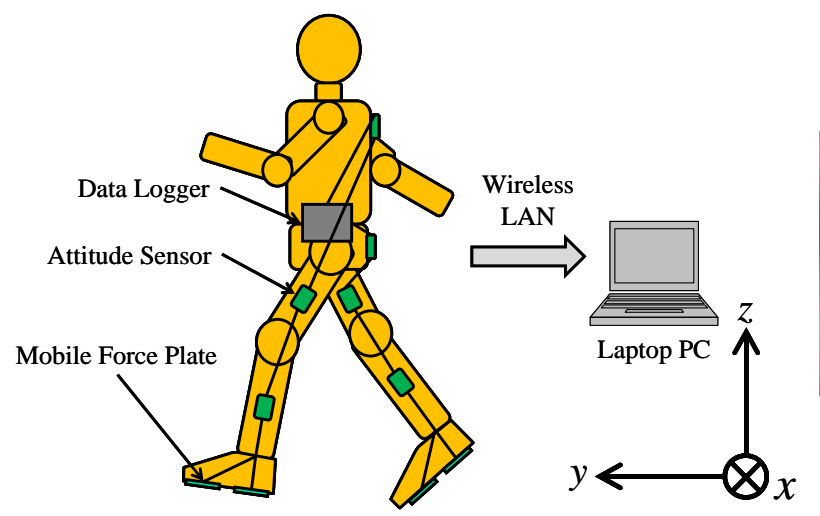

Fig. 2 Wearable gait motion analysis system. This system includes mobile force plate and attitude sensor.
Table 2 Specification of sensors in the wearable gait motion analysis system. They have satisfactory accuracies.

\begin{tabular}{c|c|c|c}
\hline \hline & Rated Value & Nonlinearity & Responsive \\
\hline Force Sensor & $\begin{array}{c}\mathrm{XY}: \pm 250[\mathrm{~N}] \\
\mathrm{Z}: \pm 500[\mathrm{~N}]\end{array}$ & $\pm 1[\% \mathrm{FS}]$ & $2[\mathrm{kHz}]$ \\
\hline Acceleration Sensor & $\pm 19.6\left[\mathrm{~m} / \mathrm{s}^{2}\right]$ & $\pm 1[\% \mathrm{FS}]$ & $500[\mathrm{~Hz}]$ \\
\hline Gyro Sensor & $\pm 1200[\mathrm{deg} / \mathrm{s}]$ & $\pm 1[\% \mathrm{FS}]$ & $140[\mathrm{~Hz}]$ \\
\hline Geomagnetic Sensor & $\pm 70000[\mathrm{nT}]$ & $\pm 0.1[\% \mathrm{FS}]$ & $10[\mathrm{~Hz}]$ \\
\hline & &
\end{tabular}

Fig. 1 Artificial knee joint of the trans-femoral prosthesis. This system can prevent giving way during gait.

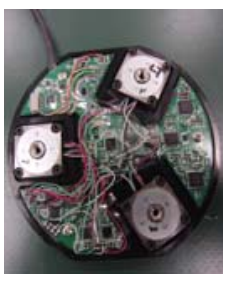

(a) Mobile force plate

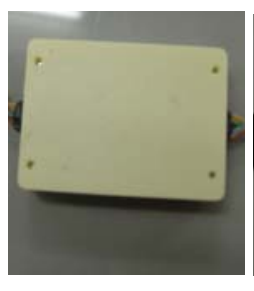

(b) Attitude sensor

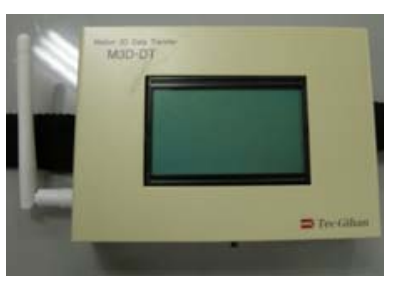

(c) Data logger
Fig. 3 Various devices consisting of the wearable gait motion analysis system. These are all lightweight for the subject.

(C) 2016 The Japan Society of Mechanical Engineers 


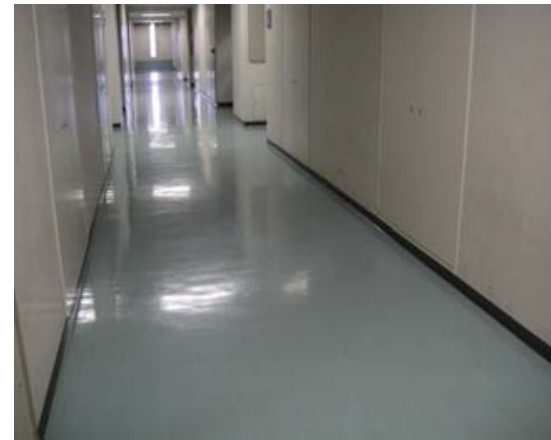

Fig. 4 Level. This floor is indoor.

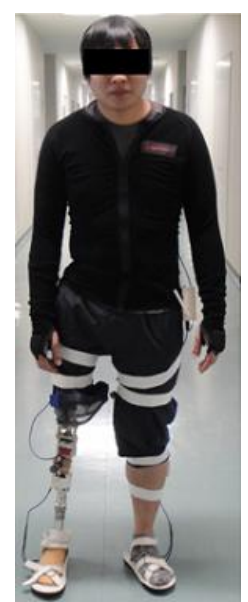

(a) Front side

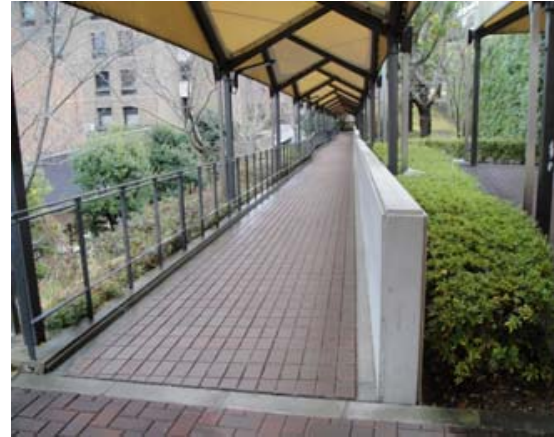

Fig. 5 Slope. This condition is used in upslopes and downslopes.

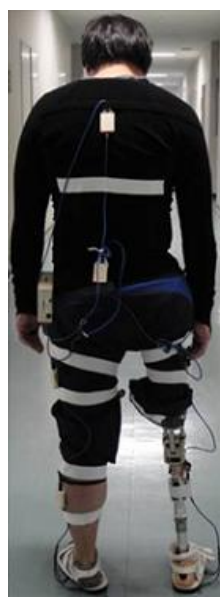

(b) Back side

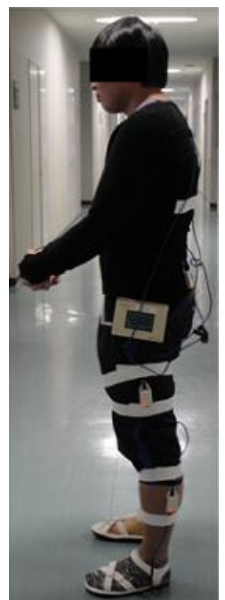

(c) Left side

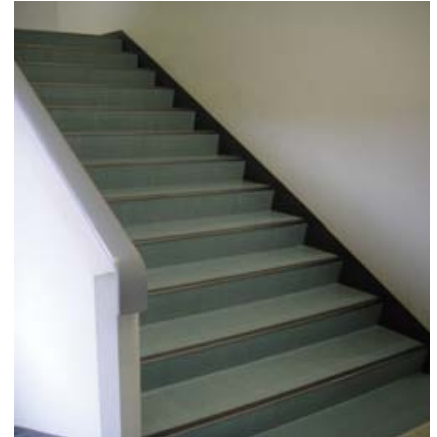

Fig. 6 Stairs. This condition is used in upstairs and downstairs.

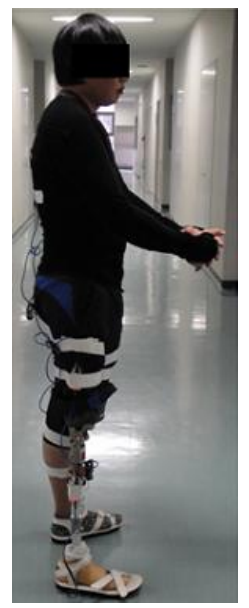

(d) Right side

Fig. 7 Subject with wearable gait motion analysis system. Dedicated suit should be worn because of unstable gait measurement.

\section{$2 \cdot 4$ データ解析手順}

前節の歩行計測実験に関するデータ解析として, 使用したウェアラブルな運動計測装置における各種出力を演 算処理することにより，反モーメントを含めた床反力，関節角度ならびに関節モーメントの算出が可能となる.

最初に, 移動式床反力計に組み込んだ小型床反力計の出力である床反力について述べる. 小型床反力計の出力 に関して, 爪先側を添字の toe, 踵側を添字の heel で表し, 移動式床反力計における片足全体の座標原点を踵側 の小型床反力計における座標原点と一致するように定義した場合, 片足全体の床反力 $\boldsymbol{F}=\left(\begin{array}{lll}F_{x} & F_{y} & F_{z}\end{array}\right)^{T}$, 反モー メント $\boldsymbol{M}=\left(\begin{array}{lll}M_{x} & M_{y} & M_{z}\end{array}\right)^{T}$ は以下の式で表される.

$$
\begin{aligned}
& \boldsymbol{F}=\left(\begin{array}{l}
F_{x} \\
F_{y} \\
F_{z}
\end{array}\right)=\left(\begin{array}{l}
F_{x \text { toe }}^{\prime}+F_{\text {xheel }}^{\prime} \\
F_{y_{\text {toe }}}^{\prime}+F_{y_{\text {heel }}}^{\prime} \\
F_{\text {ztoe }}^{\prime}+F_{\text {zheel }}^{\prime}
\end{array}\right) \\
& \boldsymbol{M}=\left(\begin{array}{l}
M_{x} \\
M_{y} \\
M_{z}
\end{array}\right)=\left(\begin{array}{l}
M_{\text {xtoe }}^{\prime}+M_{\text {xheel }}^{\prime}+F_{\text {tooe }}^{\prime} d \\
M_{y_{\text {toe }}}^{\prime}+M_{y_{\text {heel }}}^{\prime} \\
M_{z \text { toe }}^{\prime}+M_{\text {zheel }}^{\prime}-F_{\text {xtoe }}^{\prime} d
\end{array}\right)
\end{aligned}
$$

ここで， $d$ は 2 基の小型床反力計における座標原点間の距離であり,$d=0.15[\mathrm{~m}]$ である.

次に, 姿勢センサの出力から求められる関節角度, 関節モーメントについて述べる. 姿勢センサに組み込んだ 加速度センサの出力である各軸方向の加速度 $a_{x}, a_{y}, a_{z}$ を用いて, $x$ 軸周りの関節角度 $\theta_{x}$ を次式により算出する. 


$$
\theta_{x}=-\tan ^{-1} \frac{a_{y}}{\sqrt{a_{x}^{2}+a_{z}^{2}}}
$$

また， $y$ 軸周りの関節角度 $\theta_{y}$ は以下のように場合分けして算出する.

$$
\theta_{y}= \begin{cases}-\tan ^{-1}\left(\frac{a_{x}}{a_{z}}\right) & \text { if } a_{x} \neq 0 \text { and } a_{z} \leq 0 \\ -\tan ^{-1}\left(\frac{a_{x}}{a_{z}}\right)+\pi & \text { if } a_{x}>0 \text { and } a_{z}>0 \\ -\tan ^{-1}\left(\frac{a_{x}}{a_{z}}\right)-\pi & \text { if } a_{x}<0 \text { and } a_{z}>0\end{cases}
$$

さらに, $z$ 軸周りの関節角度 $\theta_{z}$ につても以下のように場合分けして算出する.ここで, 姿勢センサに組み込ん だ地磁気センサの各軸方向出力をそれぞれ $c_{x}, c_{y}, c_{z}$ とする.

$$
\theta_{z}=\left\{\begin{array}{cl}
\tan ^{-1}\left(\frac{c_{x}}{c_{y}}\right) & \text { if } c_{y} \geq 0 \\
\frac{\pi}{2} & \text { if } c_{x}>0 \text { and } c_{y}=0 \\
-\frac{\pi}{2} & \text { if } c_{x}<0 \text { and } c_{y}=0 \\
\tan ^{-1}\left(\frac{c_{x}}{c_{y}}\right)+\pi & \text { if } c_{x}>0 \text { and } c_{y}<0 \\
\tan ^{-1}\left(\frac{c_{x}}{c_{y}}\right)-\pi & \text { if } c_{x}<0 \text { and } c_{y}<0
\end{array}\right.
$$

各関節モーメントについて考えると, 足関節に生じる $x, y, z$ 軸周りのモーメント $M_{\text {xankle }}, M_{y_{\text {ankle }}}, M_{\text {zankle }}$ はそ れぞれ次式で求められる.

$$
\begin{aligned}
& M_{\text {xankle }}=l_{y 1} F_{z \text { toe }}^{\prime}-l_{z 1} F_{y \text { toe }}^{\prime}+l_{y 4} F_{z \text { heel }}^{\prime}-l_{z 4} F_{y \text { heel }}^{\prime}-l_{y 7} m_{\text {foot }} g+M_{x t o e}^{\prime}+M_{x h e e l}^{\prime}+\left\{m_{\text {foot }}\left(l_{y 7}{ }^{2}+l_{z 7}{ }^{2}\right)+I_{x 1} \ddot{\theta}_{x 1}\right. \\
& M_{y_{\text {ankle }}}=l_{z 1} F_{x \text { toe }}^{\prime}-l_{x 1} F_{z \text { toe }}^{\prime}+l_{z 4} F_{x h e e l}^{\prime}-l_{x 4} F_{z \text { heel }}^{\prime}+l_{x 7} m_{\text {foot }} g+M_{y_{\text {toe }}}^{\prime}+M_{y_{\text {heel }}}^{\prime}+\left\{m_{\text {foot }}\left(l_{x 7}{ }^{2}+l_{z 7}{ }^{2}\right)+I_{y 1}\right\} \ddot{\theta}_{y 1} \\
& M_{\text {zankle }}=l_{x 1} F_{y_{\text {toe }}}^{\prime}-l_{y 1} F_{x \text { toe }}^{\prime}+l_{x 4} F_{y_{\text {heel }}}^{\prime}-l_{y 4} F_{\text {xheel }}^{\prime}+M_{z \text { toe }}^{\prime}+M_{z \text { heel }}^{\prime}+\left\{m_{\text {foot }}\left(l_{x 7}{ }^{2}+l_{y 7}{ }^{2}\right)+I_{z 1}\right\} \ddot{\theta}_{z 1}
\end{aligned}
$$

また，膝関節に生じる $x, y, z$ 軸周りのモーメント $M_{x k n e e}, M_{y_{k n e e}}, M_{z k n e e}$ は次式で求められる.

$$
\begin{aligned}
M_{x \text { knee }}= & l_{y 2} F_{z \text { toe }}^{\prime}-l_{z 2} F_{y_{\text {toe }}}^{\prime}+l_{y 5} F_{z \text { heel }}^{\prime}-l_{z 5} F_{y_{\text {heel }}}^{\prime}-\left(l_{y 8} m_{\text {foot }}+l_{y 9} m_{\text {shank }}\right) g \\
& +M_{x \text { toe }}^{\prime}+M_{x \text { heel }}^{\prime}+\left\{m_{\text {foot }}\left(l_{y 8}{ }^{2}+l_{z 8}{ }^{2}\right)+I_{x 1} \ddot{\theta}_{x 1}+\left\{m_{\text {shank }}\left(l_{y 9}{ }^{2}+l_{z 9}{ }^{2}\right)+I_{x 2}\right\} \ddot{\theta}_{x 2}\right. \\
M_{y_{\text {knee }}}= & l_{z 2} F_{x \text { toe }}^{\prime}-l_{x 2} F_{z \text { toe }}^{\prime}+l_{z 5} F_{x h e e l}^{\prime}-l_{x 5} F_{z \text { heel }}^{\prime}+\left(l_{x 8} m_{\text {foot }}+l_{x 9} m_{\text {shank }}\right) g \\
& +M_{y_{\text {toe }}}^{\prime}+M_{y \text { heel }}^{\prime}+\left\{m_{\text {foot }}\left(l_{x 8}{ }^{2}+l_{z 8}{ }^{2}\right)+I_{y 1} \ddot{\theta}_{y 1}+\left\{m_{\text {shank }}\left(l_{x 9}{ }^{2}+l_{z 9}{ }^{2}\right)+I_{y 2}\right\} \ddot{\theta}_{y 2}\right. \\
M_{z \text { knee }}= & l_{x 22} F_{y_{\text {toe }}}^{\prime}-l_{y 2} F_{x \text { toe }}^{\prime}+l_{x 5} F_{y_{\text {heel }}}^{\prime}-l_{y 5} F_{\text {xheel }}^{\prime}+M_{z \text { toe }}+M_{z \text { heel }}^{\prime} \\
& +\left\{m_{\text {foot }}\left(l_{x 8}{ }^{2}+l_{y 8}{ }^{2}\right)+I_{z 1}\right\} \ddot{\theta}_{z 1}+\left\{m_{\text {shank }}\left(l_{x 9}{ }^{2}+l_{y 9}{ }^{2}\right)+I_{z 2}\right\} \ddot{\theta}_{z 2}
\end{aligned}
$$


さらに, 股関節に生じる $x, y, z$ 軸周りのモーメント $M_{x h i p}, M_{y_{h i p}}, M_{z h i p}$ は次式で求められる.

$$
\begin{aligned}
M_{\text {xhip }}= & l_{y 3} F_{z \text { toe }}^{\prime}-l_{z 3} F_{y_{\text {toe }}}^{\prime}+l_{y 6} F_{z \text { heel }}^{\prime}-l_{z 6} F_{y \text { heel }}^{\prime}-\left(l_{y 10} m_{\text {foot }}+l_{y 11} m_{\text {shank }}+l_{y 12} m_{\text {thigh }}\right) g+M_{x \text { toe }}^{\prime}+M_{x h \text { hel }}^{\prime} \\
& +\left\{m_{\text {foot }}\left(l_{y 10}{ }^{2}+l_{z 10}{ }^{2}\right)+I_{x 1}\right\} \ddot{\theta}_{x 1}+\left\{m_{\text {shank }}\left(l_{y 11}{ }^{2}+l_{z 11}{ }^{2}\right)+I_{x 2}\right\} \ddot{\theta}_{x 2}+\left\{m_{\text {thigh }}\left(l_{y 12}{ }^{2}+l_{z 12}{ }^{2}\right)+I_{x 3}\right\} \ddot{\theta}_{x 3} \\
M_{y \text { hip }}= & l_{z 3} F_{x \text { toe }}^{\prime}-l_{x 3} F_{z \text { toe }}^{\prime}+l_{z 6} F_{x h e e l}^{\prime}-l_{x 6} F_{z h e l}^{\prime}+\left(l_{x 10} m_{\text {foot }}+l_{x 11} m_{\text {shank }}+l_{x 12} m_{\text {thigh }}\right) g+M_{y_{\text {toe }}}^{\prime}+M_{y \text { heel }}^{\prime} \\
& +\left\{m_{\text {foot }}\left(l_{x 10}{ }^{2}+l_{z 10}{ }^{2}\right)+I_{y 1}\right\} \ddot{\theta}_{y 1}+\left\{m_{\text {shank }}\left(l_{x 11}{ }^{2}+l_{z 11}{ }^{2}\right)+I_{y 2}\right\} \ddot{\theta}_{y 2}+\left\{m_{\text {thigh }}\left(l_{x 12}{ }^{2}+l_{z 12}{ }^{2}\right)+I_{y 3} \ddot{\theta}_{y 3}\right. \\
M_{z h i p}= & l_{x 3} F_{y \text { toe }}^{\prime}-l_{y 3} F_{x t o e}^{\prime}+l_{x 6} F_{y \text { heel }}^{\prime}-l_{y 6} F_{x h e e l}^{\prime}+M_{z \text { toe }}^{\prime}+M_{z \text { heel }}^{\prime} \\
& +\left\{m_{\text {foot }}\left(l_{x 10}{ }^{2}+l_{y 10}{ }^{2}\right)+I_{z 1}\right\} \ddot{\theta}_{z 1}+\left\{m_{\text {shank }}\left(l_{x 11}{ }^{2}+l_{y 11}{ }^{2}\right)+I_{z 2}\right\} \ddot{\theta}_{z 2}+\left\{m_{\text {thigh }}\left(l_{x 12}{ }^{2}+l_{y 12}{ }^{2}\right)+I_{z 3}\right\} \ddot{\theta}_{z 3}
\end{aligned}
$$

ここで, $g$ は重力加速度, $m_{\text {foot }}, m_{\text {shank }}, m_{\text {thigh }}$ は独立行政法人産業技術総合研究所デジタルヒューマン工学センタ 一の「慣性特性データベース」において公開されている人体特性(Zatsiorsky, 1983)から得られた足部，下腿部，大 腿部の質量, $\ddot{\theta}_{x j}, \ddot{\theta}_{y j}, \ddot{\theta}_{z j}(j=1,2,3)$ は姿勢センサに組み込んだジャイロセンサの出力を微分して得られた足, 膝,

股関節の $x, y, z$ 軸周りに生じる角加速度, $I_{x j}, I_{y j}, I_{z j}(j=1,2,3)$ は人体特性(Zatsiorsky, 1983)から得られた足部,

下腿部，大腿部の慣性モーメント， $l_{x 1}, \ldots, l_{x 12}, l_{y 1}, \ldots, l_{y 12}, l_{z 1}, \ldots, l_{z 12}$ は順に計測した足，膝，股関節からつま先側 の小型床反力計における座標原点までの $x$ 軸方向距離, 足, 膝, 股関節から足底圧中心点までの $x$ 軸方向距離, 足関節から足部の質量中心点までの $x$ 軸方向距離，膝関節から足部および下腿部の質量中心点までの $x$ 軸方向距 離，股関節から足部，下腿部，大腿部の質量中心点までの $x$ 軸方向距離，足，膝，股関節からつま先側の小型床 反力計における座標原点までの $y$ 軸方向距離，足，膝，股関節から足底圧中心点までの $y$ 軸方向距離，足関節か ら足部の質量中心点までの $y$ 軸方向距離, 膝関節から足部および下腿部の質量中心点までの $y$ 軸方向距離, 股関 節から足部，下腿部，大腿部の質量中心点までの $y$ 軸方向距離，足，膝，股関節からつま先側の小型床反力計に おける座標原点までの $\mathrm{z}$ 軸方向距離，足，膝，股関節から足底圧中心点までの $\mathrm{z}$ 軸方向距離，足関節から足部の 質量中心点までの $z$ 軸方向距離，膝関節から足部および下腿部の質量中心点までの $z$ 軸方向距離，股関節から足 部，下腿部，大腿部の質量中心点までの $z$ 軸方向距離を表し，これらは正負の值をとるものとする.

なお，関節角度や関節モーメントの各軸周り回転方向は図 8 に示すように右ねじの方向を正とする. 本研究に おいて，大腿義足装着者の関節モーメントに関しては義足側では人体特性によるデータを用いることができない ため，健足側に関してのみ関節モーメントを算出し，義足側では関節角度のみを算出した形とする.

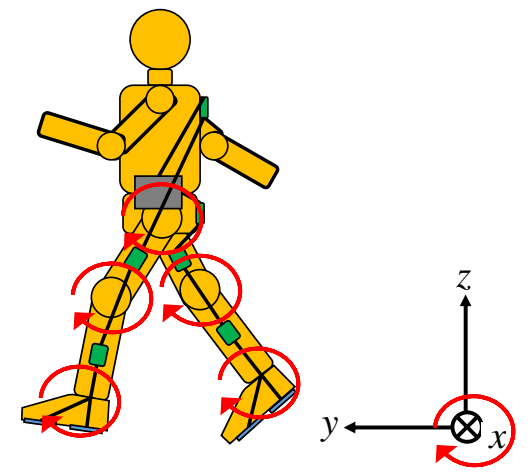

Fig. 8 Definition of positive directions concerning joint angles and moments. Red curly arrows mean those directions.

\section{3. 関節間協調動作の評価手法}

本研究では，大腿義足装着者の歩行における下肢の関節周りに生じる回転運動をはじめとする関節間協調動作 の主成分を解析するため，これまでに提案された特異值分解の原理に基づく関節角度を用いた評価手法およびそ の適用例(舩戸他, 2010)に加えて, 新たに関節モーメントの要素を含めた評価手法(林他, 2015b)を適用する. 以 
下, $\theta_{\text {ankle }}(t), \theta_{\text {knee }}(t), \theta_{\text {hip }}(t)$ を足, 膝, 股関節の関節角度, $M_{\text {ankle }}(t), M_{\text {knee }}(t), M_{\text {hip }}(t)$ を足, 膝, 股 関節に生じる関節モーメントの時系列形式とする。これらを順番に並べた各関節周りに生じる関節角度と関節モ ーメントの算出データを標準化した時系列データパターン $\bar{\theta}_{j}\left(t_{i}\right), \bar{M}_{j}\left(t_{i}\right)(i=1, \ldots, m, j=1, \ldots, r \leq n)$ を用い て以下の行列式で表す.

$$
\overline{\boldsymbol{R}}(\bar{\theta}, \bar{M}, t)=\left(\begin{array}{cccccc}
\bar{\theta}_{1}\left(t_{1}\right) & \cdots & \bar{\theta}_{p}\left(t_{1}\right) & \bar{M}_{1}\left(t_{1}\right) & \cdots & \bar{M}_{q}\left(t_{1}\right) \\
\vdots & \ddots & \vdots & \vdots & \ddots & \vdots \\
\bar{\theta}_{1}\left(t_{m}\right) & \cdots & \bar{\theta}_{p}\left(t_{m}\right) & \bar{M}_{1}\left(t_{m}\right) & \cdots & \bar{M}_{q}\left(t_{m}\right)
\end{array}\right)
$$

この行列を観測行列と定義する. $m, n, p, q$ はデータ数であり, $n(=p+q), p, q \in r$ とする. 次に, 観測行 列 $\overline{\boldsymbol{R}}(\bar{\theta}, \bar{M}, t)$ に対して特異值分解を施す。特異值分解を用いて, 関節角度と関節モーメントを互いに直交する 基底ベクトルで展開している. ここで, $\overline{\boldsymbol{R}}(\bar{\theta}, \bar{M}, t)$ の特異值を $\lambda_{j}, \overline{\boldsymbol{R}}(\bar{\theta}, \bar{M}, t) \overline{\boldsymbol{R}}(\bar{\theta}, \bar{M}, t)^{T}$ の特異ベクトル を $\boldsymbol{v}_{j}(t), \overline{\boldsymbol{R}}(\bar{\theta}, \bar{M}, t)^{T} \overline{\boldsymbol{R}}(\bar{\theta}, \bar{M}, t)$ の特異ベクトルを $\mathbf{z}_{j}(\bar{\theta}, \bar{M})$ とすると， $\overline{\boldsymbol{R}}(\bar{\theta}, \bar{M}, t)$ は次式で表せる.

$$
\overline{\boldsymbol{R}}(\bar{\theta}, \bar{M}, t)=\sum_{j=1}^{n} \lambda_{j} \cdot \boldsymbol{v}_{j}(t) \cdot \mathbf{z}_{j}{ }^{T}(\bar{\theta}, \bar{M})
$$

ここで, $\lambda_{j}$ は特異值の大きい順に第 1 モード, 第 2 モードとした運動モードと呼ばれる各正規直交基底ベクトル の寄与率であり, $\boldsymbol{v}_{j}(t)$ は各基底の活動パターン, $\mathbf{z}_{j}(\bar{\theta}, \bar{M})$ は各基底における物理量の協調パターンを表し，そ れぞれ時間基底, 空間基底と呼ぶ.さらに, 観測されたすべての運動モードに対する $j$ 番目の特異值 $\lambda_{j}$ が持つ寄 与率 $\gamma_{j}$ は以下の式で表すことができる. 本研究では, この寄与率を割合表示して最も大きなモードを考慮する.

$$
\gamma_{j}=\lambda_{j}^{2} / \sum_{j=1}^{n} \lambda_{j}^{2}
$$

\section{4. 解析結果および考察}

得られた解析結果の一例として, 前章において述べた手法を運動計測データの各物理量に対して適用した結果, 各路面環境のパターンにおいて算出した運動モードのうち最も支配的なモードにおける, 各物理量の正負で表さ れる寄与の大きさである空間基底をそれぞれ図 9～図 28 に示す.このうち, 図 9, 図 10, 図 13, 図 14, 図 17, 図 18, 図 21, 図 22, 図 25, 図 26 は大腿義足装着者の健足側である左脚の一歩行周期における関節角度および関

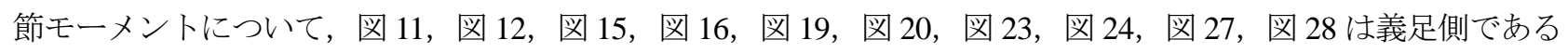
右脚の一歩行周期における関節角度 $\theta_{\text {ankle }}^{\prime}, \theta_{\text {knee }}^{\prime}, \theta_{h i p}^{\prime}$ およびその間に生じる健足側の関節角度について算出した空 間基底である。 なお, 図 9, 図 10, 図 13, 図 14, 図 17, 図 18, 図 21, 図 22, 図 25, 図 26 ならびに図 11 , 図 12, 図 15, 図 16, 図 19, 図 20, 図 23, 図 24, 図 27, 図 28 における $\theta_{\text {ankle }}, \theta_{\text {knee }}, \theta_{\text {hip }}$ は各値として互いに異なる. ここで，空間基底とは，前節で触れたように，関節角度および関節モーメントといった物理量について単位や次 元の違いを排除するために值を標準化した時系列データの観測行列を特異值分解し, 得られた運動の主成分を表 す正規直交基底べクトルである特異ベクトルにおける各物理量に対応する，-1 から 1 までの大きさで表される客 観的な指標としての無次元量の主成分ベクトルであり，1 に近いと座標系における正の方向に大きく働いて全体 の運動に寄与しており，逆に-1 に近いと座標系における負の方向に大きく働いて全体の運動に寄与しており，0 に近いと物理量としてほとんど働いておらず全体の運動に寄与していないことを表している．また，寄与率につ 
いては，平地，斜面および階段の上り下りのいずれの路面状況においても立脚期・遊脚期ともに図 9〜図 18 では 第 2 モードまで，図 19〜図 28 では第 3 モードまでの累積寄与率の和が 90 [\%]を超える形となり，これらの運動 モードで歩行運動は構成されているといえる. 以下，本章では寄与率が最大であり最も代表的と考えられる第 1 モードについて記述し，各地形におけるパターンごとの足・膝ならびに股関節の角度およびモーメントといった 計 6 種類の歩行を現象的に表しているそれぞれの物理量の運動全体に対する寄与率の大小，正負に言及し，相互 比較をおこない生体力学的に考察する. なお, 以下では空間基底における関節角度および関節モーメントの正負 とそれらに対応する身体の解剖学的な運動方向について, 図 8 に示したように正の方向を定義する. 具体的には, 足関節では図 8 における右㸚じの方向を正の方向とみなし，背屈を正，底屈を負というように定義し，膝・股関 節では足関節の場合と同様の理由から, それぞれ伸展を正, 屈曲を負と定義し, 屈曲を正, 伸展を負と定義する.

\section{$4 \cdot 1$ 平地}

平地における立脚期・遊脚期の空間基底を健足側に関して図 9, 図 10，義足側に関して図 11，図 12 に示寸. 健足側では図 9 より, 立脚期の代表的な運動の特徵である足関節の底屈運動と背屈モーメントが作用していると 考えられる.また，遊脚期においては図 10 より，浮かせた下肢を前方に持っていく振り出しをおこなう前に後方 に対して振り上げる動作をするため，各関節はいずれも股関節が伸展する方向と同じ方向に運動し，加えてその ためにそれらと同じ方向のモーメントがそれぞれに作用していることを表していると考えられる．他方，義足側 では図 11, 図 12 から, 立脚期において足部の足関節で強く底屈し踏み込む動作, ならびに使用したバウンシン グ膝継手の特徵である膝関節の軽度屈曲を実現できており, 股関節では前方に踏み出そうとして屈曲方向の動作 が生じていることが読み取れる，その間，健足側では義足側によって身体を支えている不安定性をカバーするた め, 膝関節を動かさずに足関節と股関節のみを後方に振り上げる方向の動作をおこなっていると考えられる.ま た，遊脚期においては義足側がいずれの関節ともに後方に振り上げる動作をおこなっていることに対して健足側 の膝関節が屈曲し重心を低くして姿勢を安定させ，健常者の場合(林他，2015a) と異なり健足側の股関節が屈曲し バランスを取っていると考えられる.

\section{$4 \cdot 2$ 斜面}

斜面上りにおける立脚期・遊脚期の空間基底を健足側に関して図 13, 図 14, 義足側に関して図 15, 図 16 に示 す. 健足側では, 図 13 より立脚期において膝関節が大きく屈曲し地面を蹴り出すため伸展モーメントが作用して いると考えられる. また, 遊脚期においては図 14 より平地と同様の現象が生じていることが考えられる. 他方, 義足側においては図 15, 図 16 より, 平地における図 11, 図 12 と比較して立脚期では正負がほぼ逆になった空間 基底の值を示しているが健足側の膝関節が屈曲する動作が表れており, 遊脚期では類似しているが義足側の膝関 節について運動が少なく, 健足側の足関節が逆に底屈していることが読み取れる. これらは, 立脚期では平地と 比較して歩行動作としては同様であったが，後方への振り上げと前方への振り出しのように動作として対称であ り逆向きのものが存在するように, 平地よりも前進するための全体的な運動と力が必要であることから対称的か つ逆向きの動作が前進寸るために必要となり，健足側では下肢に勢いをつけるために膝関節を屈曲させたと考え られ，遊脚期では義足側で下肢に勢いをつける際に膝関節の可動性がなく，それを補うために健足側で足関節を 底屈させて強く踏み込んでいたと考えられる。

斜面下りにおける立脚期・遊脚期の空間基底を健足側に関して図 17, 図 18, 義足側に関して図 19, 図 20 に示 す. 健足側では図 17 より，立脚期において膝・股関節はともに伸展しているといえる. 遊脚期においては図 18 より平地と同様の現象が生じているといえる. 他方, 義足側においては, 立脚期では図 19 より姿勢を維持するた め床面に対して強く踏み込み足関節が底屈し膝関節は運動が少なくなり股関節は屈曲させバランスを取っている といえ，遊脚期では図 20 より膝・股関節から前方への振り出しが生じているといえる.

\section{$4 \cdot 3$ 階段}

階段上りにおける立脚期・遊脚期の空間基底を健足側に関して図 21, 図 22, 義足側に関して図 23, 図 24 に示 す. 健足側では, 図 21 より立脚期において体重心を上方に持ち上げなければならないため, 屈曲させた膝関節を 伸展させる伸展モーメントが作用し, 義足側の不安定性から重心を低くしバランスを取るため股関節の屈曲モー メントが大きく働いていると考えられる. また, 遊脚期においては, 図 22 より次の段に接地するために足関節が 
底屈した上，股関節が伸展し，さらに各関節においても同じ方向に運動させるためモーメントが作用していると 考えられる. 他方，義足側では図 23 より，立脚期においては足関節が底屈し，逆に膝関節では伸展する方向に角 度成分が働き，その間に健足側では足関節が底屈し，膝関節と股関節が伸展していることが読み取れる．これら は，本研究における大腿義足歩行では階段を昇る際に義足側の膝継手において能動的に昇る機能を有していない ため，健足側が遊脚期となり先に段を昇り軸足となることにしたがって義足側を昇らせることに基づき，その際 に義足側は姿勢を維持するため床面に対して踏み込み足関節が底屈し, 膝関節は伸展しており, 健足側は段に着 地するため足関節を底屈させ, 膝関節と股関節を伸展させていると考えられる. 遊脚期では, 図 24 より能動的で なく健足側に引っ張られる形で次の段に昇るため, 足関節における次の段への踏み込みによる底屈が生じ，脚が 段を超えた後に足を段に乗せるため，股関節は伸展し姿勢を維持しており，足先が段に当たらないよう膝関節を 屈曲させていると考えられる.

階段下りにおける立脚期・遊脚期の空間基底を健足側に関して図 25，図 26，義足側に関して図 27，図 28 に示 す. 健足側では図 25 より, 立脚期において体重心の急な落下を防ぐため足関節は背屈モーメントを発生しながら 底屈させて運動を抑制し，義足側を次の段に降ろ寸際に股関節は伸展し姿勢を維持していることが読み取れる. また, 遊脚期においては図 26 より次の段に接地するために膝関節が屈曲し股関節が屈曲していると考えられる. さらに，股関節においては過度の屈曲を抑えるために伸展モーメントが作用していると考えられる．他方，義足 側では，立脚期において図 27 より，不安定性から全体的に膝関節が伸展し切って突っ張ったような状態となり， その間, 健足側は次の段に降りる動作をしているといえる. 遊脚期においては, 図 28 より能動的でなく健足側を 支えとして次の段に降万すため膝関節の運動が少なく, 足関節における次の段への踏み込みによる底屈が生じ, 股関節は伸展し姿勢を維持していることが読み取れる．その間，体重心の急な落下を防ぐため健足側の足関節は 背屈し，膝関節では屈曲により体重心を低くして姿勢を安定させていると考えられる.

以上のことから, 本研究において特徵量として抽出ならびに解析した大腿義足歩行における関節角度および関 節モーメントで表される歩行運動の全体空間に対する数值データに基づき，日常生活環境を反映した路面におい いて生じる構成因子としての基礎的な運動パターンに関して, 定量的な指標を用いて評価, 表現できたといえる.

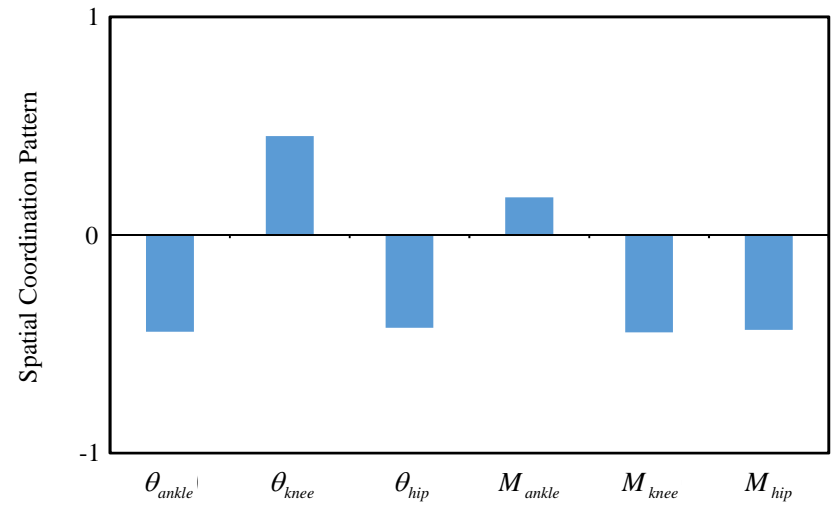

Fig. 9 Spatial coordination of stance phase in the sound limb of level walking. Values run from -1 through 1.

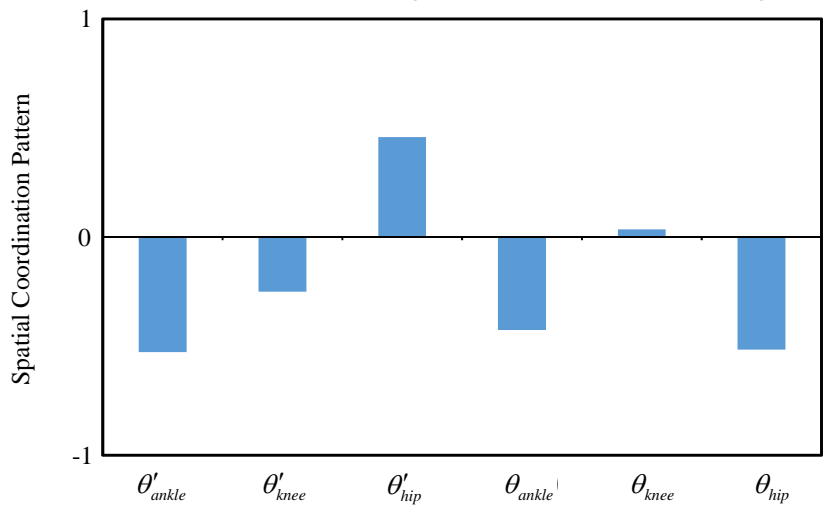

Fig. 11 Spatial coordination of stance phase in the prosthetic limb of level walking. Values run from -1 through 1.

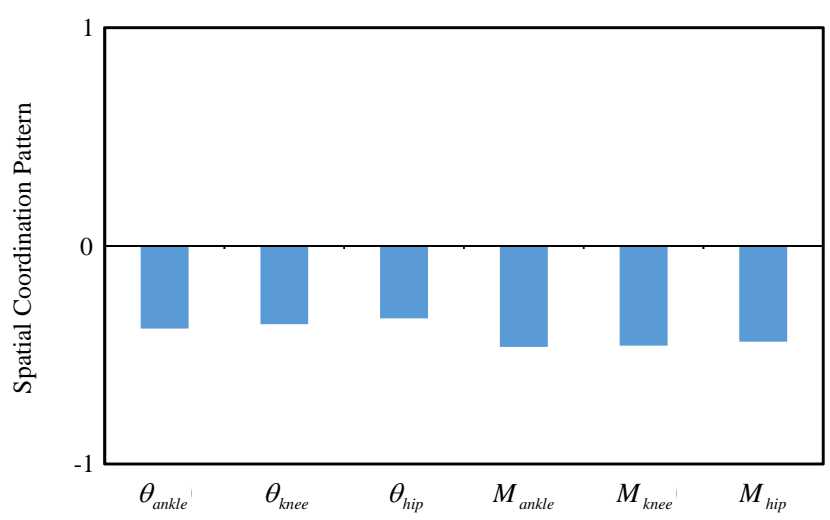

Fig. 10 Spatial coordination of swing phase in the sound limb of level walking. Values run from -1 through 1.

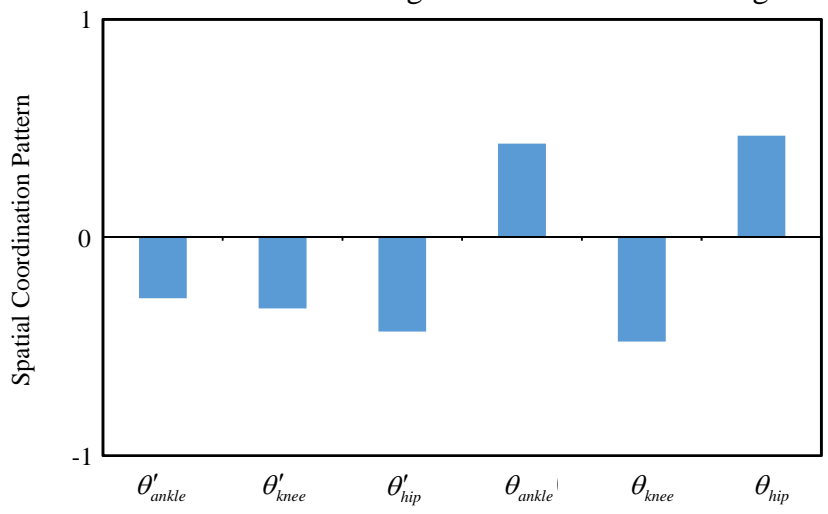

Fig. 12 Spatial coordination of swing phase in the prosthetic limb of level walking. Values run from -1 through 1. 


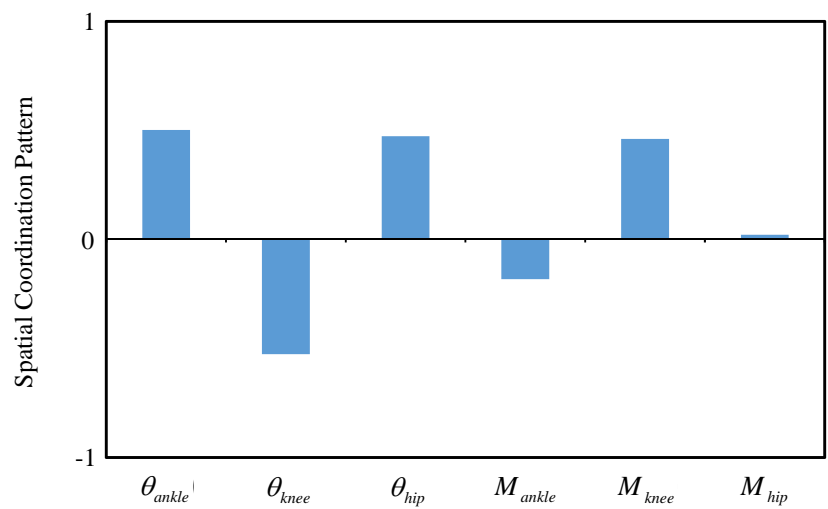

Fig. 13 Spatial coordination of stance phase in the sound limb of upslopes. Values run from -1 through 1.

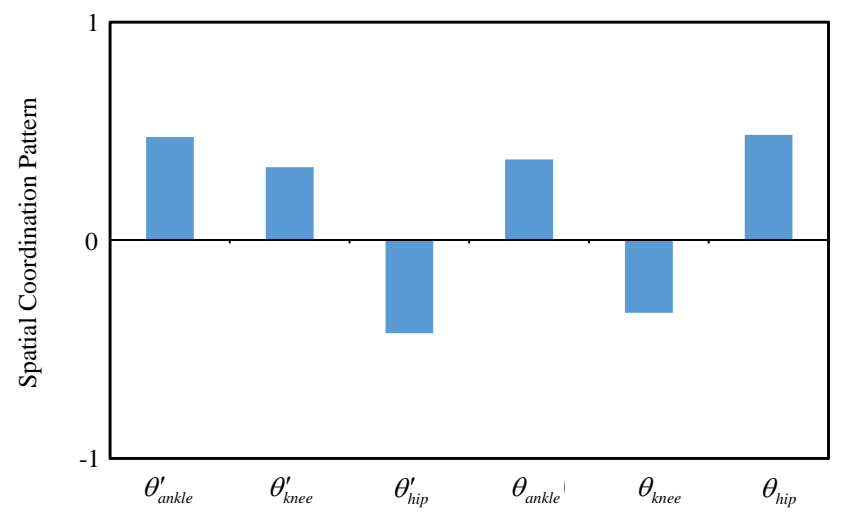

Fig. 15 Spatial coordination of stance phase in the prosthetic limb of upslopes. Values run from -1 through 1.

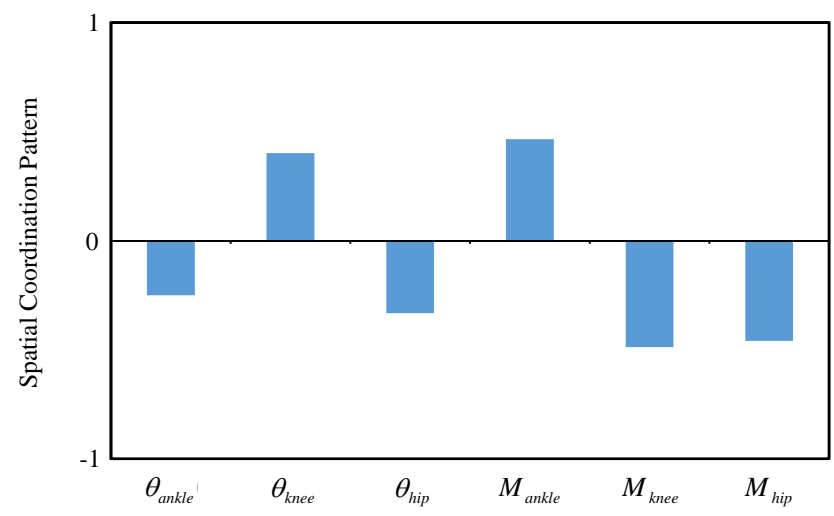

Fig. 17 Spatial coordination of stance phase in the sound limb of downslopes. Values run from -1 through 1 .

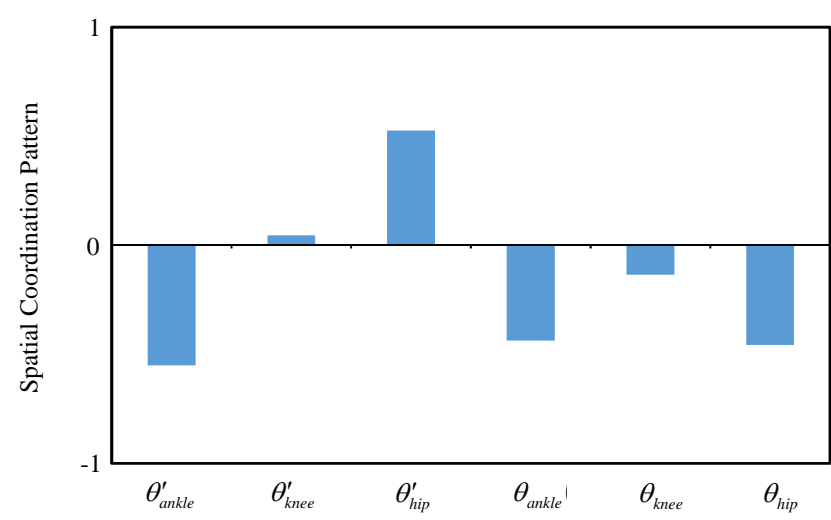

Fig. 19 Spatial coordination of stance phase in the prosthetic limb of downslopes. Values run from -1 through 1.

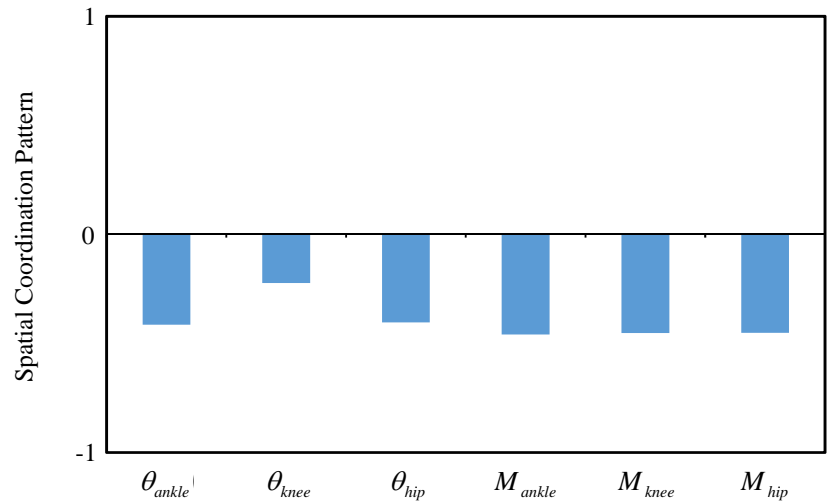

Fig. 14 Spatial coordination of swing phase in the sound limb of upslopes. Values run from -1 through 1.

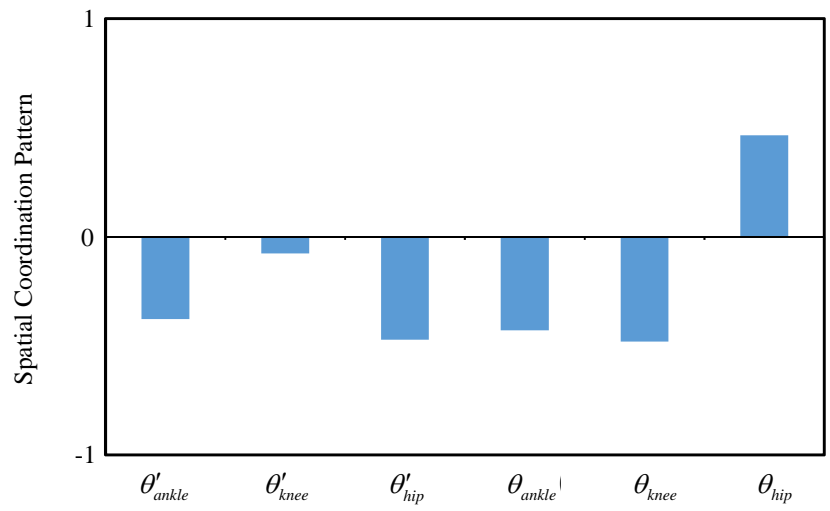

Fig. 16 Spatial coordination of swing phase in the prosthetic limb of upslopes. Values run from -1 through 1.

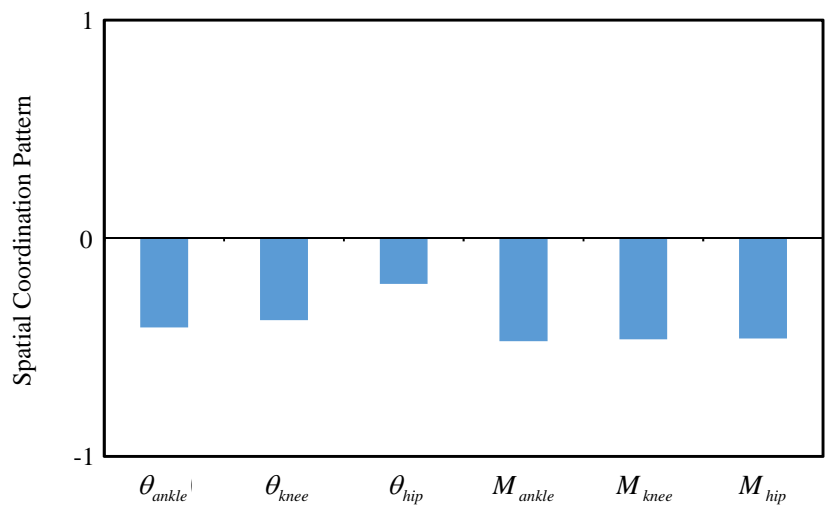

Fig. 18 Spatial coordination of swing phase in the sound limb of downslopes. Values run from -1 through 1 .

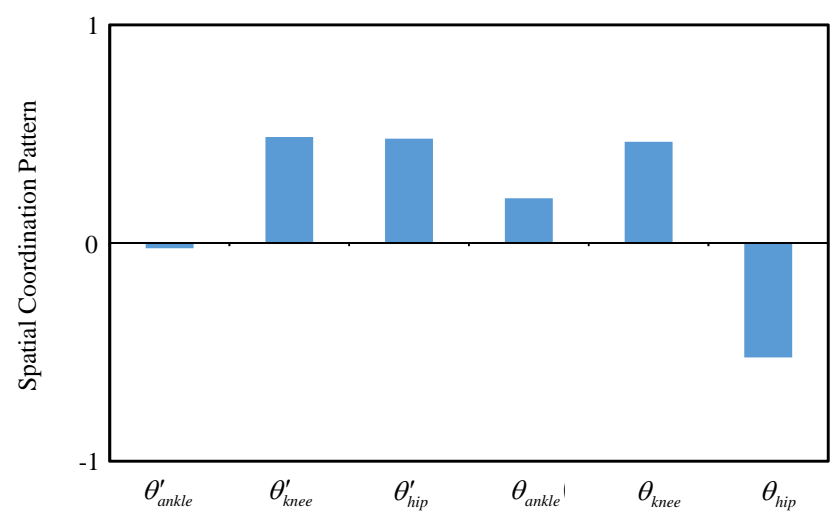

Fig. 20 Spatial coordination of swing phase in the prosthetic limb of downslopes. Values run from -1 through 1. 


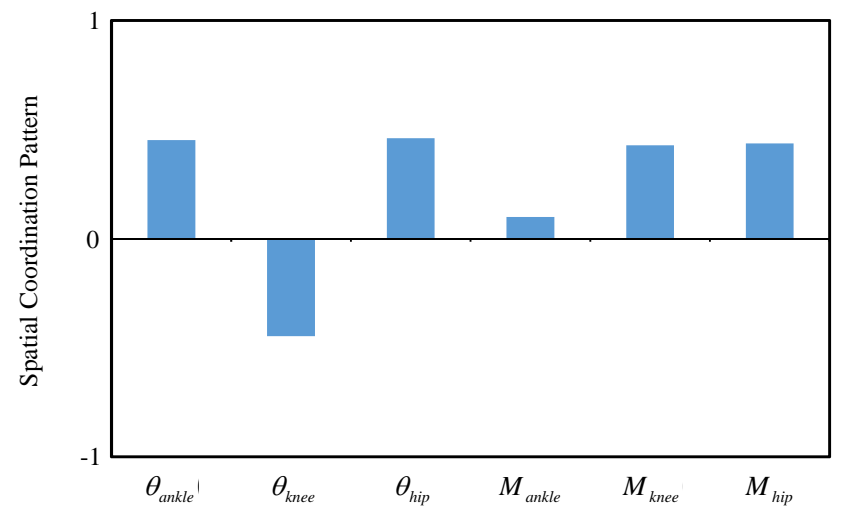

Fig. 21 Spatial coordination of stance phase in the sound limb of upstairs. Values run from -1 through 1.

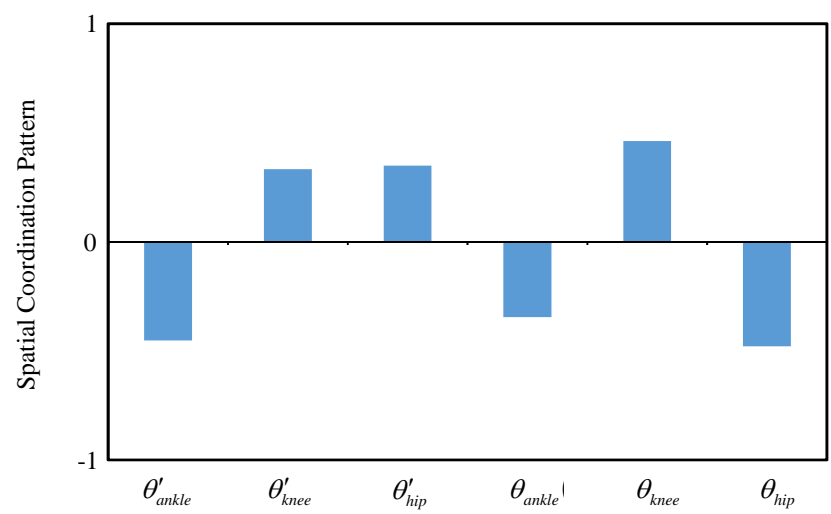

Fig. 23 Spatial coordination of stance phase in the prosthetic limb of upstairs. Values run from -1 through 1.

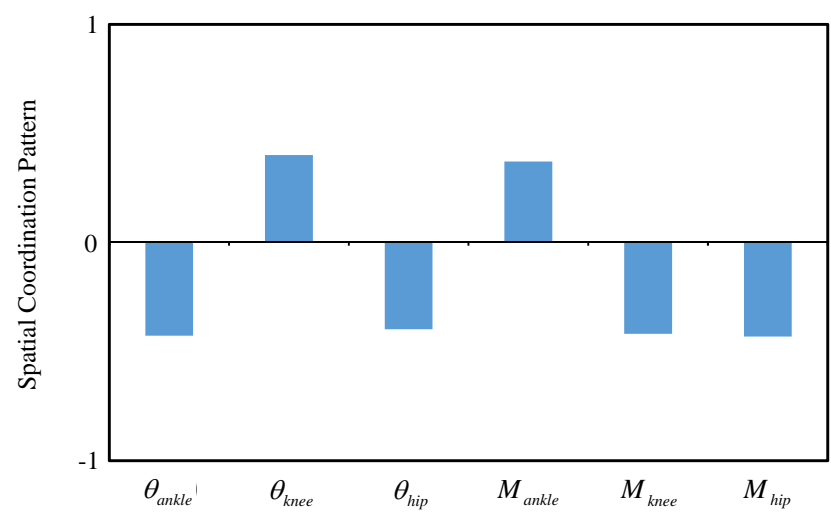

Fig. 25 Spatial coordination of stance phase in the sound limb of downstairs. Values run from -1 through 1 .

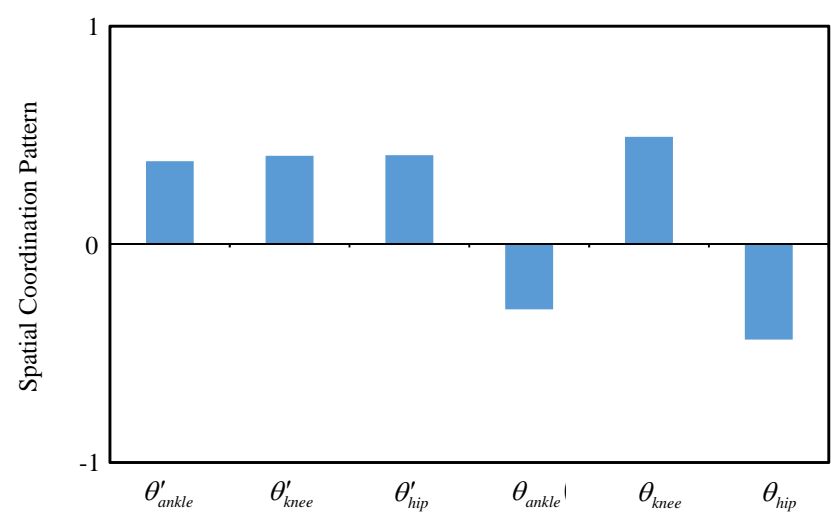

Fig. 27 Spatial coordination of stance phase in the prosthetic limb of downstairs. Values run from -1 through 1 .

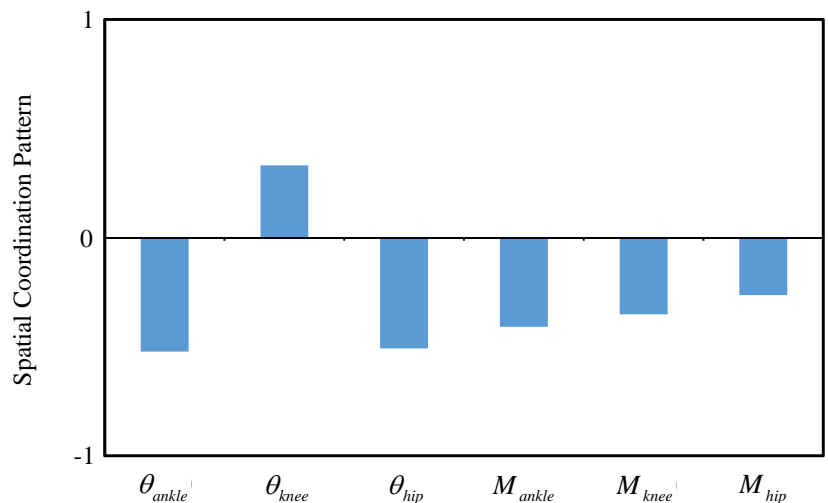

Fig. 22 Spatial coordination of swing phase in the sound limb of upstairs. Values run from -1 through 1.

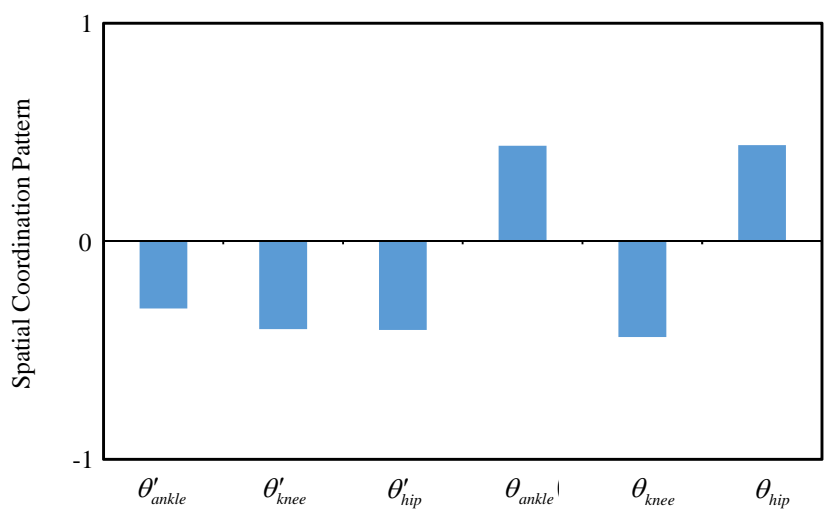

Fig. 24 Spatial coordination of swing phase in the prosthetic limb of upstairs. Values run from -1 through 1.

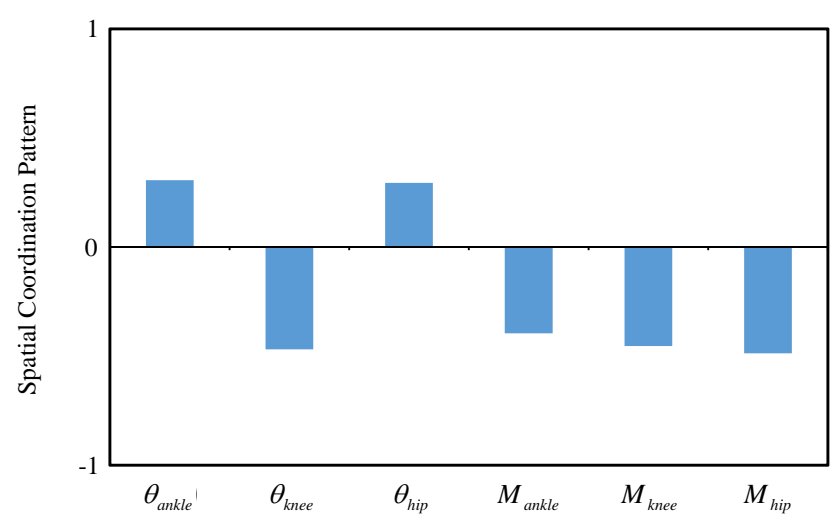

Fig. 26 Spatial coordination of swing phase in the sound limb of downstairs. Values run from -1 through 1.

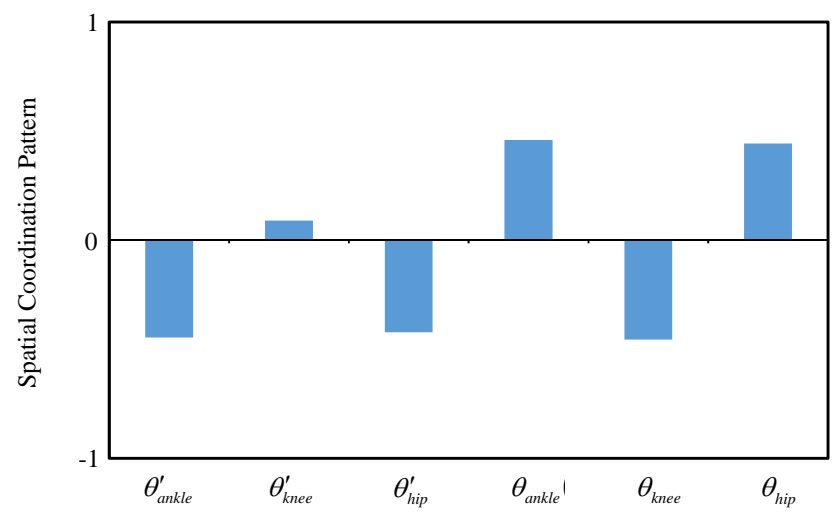

Fig. 28 Spatial coordination of swing phase in the prosthetic limb of downstairs. Values run from -1 through 1. 


\section{5. 結 言}

本研究では, 大腿義足歩行のうち代表的な日常生活動作の環境として考えられる平地に加えて斜面および階段 の上り下りの計 5 種類を路面条件に含めた計測実験を実施し, それらにおいて生じる下肢関節の回転運動を解析 した．具体的には，運動変位および運動の駆動トルクに相当する関節角度，関節モーメントに関して，主要な運 動パターンを抽出・分析するため特異值分解を施し, 得られた動作の空間的指標といえる空間基底について条件 ごとに相互比較した. また, 移動式床反力計および姿勢センサによるウェアラブルな運動計測装置の適用により， 実際的な動作の解析を実現した。 大腿義足装着者の一歩行周期のうち立脚期と遊脚期における主要な下肢関節回 転運動パターンを算出し, それらを運動学および動力学的観点から比較考察・評価した結果, 以下の結論を得た.

1. 大腿義足装着者の一般的な歩行運動に関する運動学・動力学的な各物理量で表現される主要な下肢関節の回 転運動パターンと定義されるベクトル量である空間基底をそれぞれの環境条件について算出し，遊脚期にお ける関節の前方への伸展に加えて, 斜面では地面の蹴り出しや膝・股関節の伸展や前方への振り出し, 階段 では段差に対する体重心の上下動に順応した健足側および義足側の各関節の働きなど，日常生活における各 路面環境に対応した動作が数值的・客観的に表現でき，大腿義足歩行の基礎的なパターンを表すといえる.

2. 路面環境間の物理現象としての空間的特徵の相違を表す主要な歩行運動パターンを関節角度および関節モー メントについて考慮した上で特徵量として抽出し, 下肢の全体的な身体運動の比較考察を関節の回転現象に 着目しておこないそれらの特徴を把握し, 本研究において実施した, 平地に加えて斜面・階段の上り下りを 含む実際的な日常生活環境を反映した大腿義足歩行において，提案した主成分分析に基づく各物理量に対応 する主成分ベクトルであるそれぞれの空間基底による手法を用いた歩行運動解析に関する有効性を検証した。

\section{謝 辞}

なお, 本研究の一部は日本学術振興会 科学研究費助成事業 基盤研究 (B)（研究課題番号：25289053）の補助 を受けた。ここに記して謝意を表する.

\section{文献}

江原義弘，山本澄子，関節モーメントによる歩行分析 (2001), pp. 3-134, 医歯薬出版.

江原義弘, 山本澄子, ボディダイナミクス入門 歩き始めと歩行の分析 (2002), pp. 149-167, 医歯薬出版.

舩戸徹郎, 青井伸也, 土屋和雄, ヒトの歩行における全身の関節協調動作の定量的評価, 日本ロボット学会誌,

Vol. 28, No. 8 (2010), pp. 996-1003.

林祐一郎, 辻内伸好, 小泉孝之, 松田靖史, 土屋陽太郎, 大腿義足装着者の無拘束歩行計測に基づく生体力学的

考察，日本機械学会論文集 C 編，Vol. 77, No. 784 (2011), pp. 4619-4629.

林祐一郎, 辻内伸好, 小泉孝之, 松田靖史, 土屋陽太郎, 井上喜雄, 移動式床反力計を用いた制約のない健常者

および大腿切断者の歩行運動解析，日本機械学会論文集 C 編，Vol. 79, No. 805 (2013), pp. 3059-3074.

林祐一郎, 辻内伸好, 松田靖史, 関節間協調に基づく大腿義足着用者の主要な歩行運動パターンの定量的評価,

日本機械学会論文集, Vol. 81, No. 825 (2015a), DOI : 10.1299/transjsme.15-00020.

林祐一郎, 辻内伸好, 宇野龍司, 牧野裕太, 土屋陽太郎, 階段・斜面を含む七トの歩行に生じる関節角度・モー

メントの主成分の解析, 日本機械学会論文集, Vol. 81, No. 830 (2015b), DOI : 10.1299/transjsme.15-00320.

伊藤利之, 赤居正美, 義肢装具のチェックポイント (2008), pp. 14-16, 医学書院.

川村次郎，義肢装具学 (2004), pp. 14-16, 医学書院.

北村徹, 辻内伸好, 小泉孝之, 筋電信号による動作推定に基づくロボットハンドのマニピュレーション，日本機

械学会論文集 C 編，Vol. 73, No. 735 (2007), pp. 3024-3030.

沢村誠志, 切断と義肢 (2004), pp. 1-5, 医歯薬出版.

鈴木聡一郎，大腿義足の遊脚期制御に関寸る解析的検討，日本機械学会論文集 C 編，Vol. 70, No. 695 (2004), pp. 2110-2117.

鈴木聡一郎，外部駆動源を必要としない能動型膝継手の実験的検討，日本機械学会論文集 C 編，Vol. 75, No. 756

(2009), pp. 2274-2279. 
豊田輝，山崎裕司，加藤宗規，宮城新吾，吉葉崇，練習方法の違いが模擬大腿義足歩行技能に及ぼす影響につい て, 理学療法科学, Vol. 23, No. 1 (2008), pp. 67-71.

Zatsiorsky, V., The mass and inertia characteristics of the main segments of the human body, Biomechanics VIII-B (1983), pp. 1152-1159.

\section{References}

Ehara, Y. and Yamamoto, S., Gait analysis by joint moment (2001), pp. 3-134, Ishiyaku Publishers, Inc (in Japanese).

Ehara, Y. and Yamamoto, S., Introduction to body dynamics: analysis of begin walking and gait (2002), pp. 149-167, Ishiyaku Publishers, Inc (in Japanese).

Funato, T., Aoi, S. and Tsuchiya, K., Quantitative evaluation of the intersegmental coordination during human locomotion, Journal of the Robotics Society of Japan, Vol. 28, No. 8 (2010), pp. 996-1003 (in Japanese).

Hayashi, Y., Tsujiuchi, N., Koizumi, T., Matsuda, Y. and Tsuchiya, Y., Biomechanical consideration based on the unrestrained gait measurement in trans-femoral amputee with a prosthetic limb, Transactions of the Japan Society of Mechanical Engineers, Series C, Vol. 77, No. 784 (2011), pp. 4619-4629 (in Japanese).

Hayashi, Y., Tsujiuchi, N., Koizumi, T., Matsuda, Y., Tsuchiya, Y. and Inoue, Y., Unrestrained human gait motion analysis of healthy subjects and trans-femoral amputee using mobile force plate, Transactions of the Japan Society of Mechanical Engineers, Series C, Vol. 79, No. 805 (2013), pp. 3059-3074 (in Japanese).

Hayashi, Y., Tsujiuchi, N. and Matsuda, Y., Quantitative evaluation concerning principal gait locomotion pattern of a trans-femoral amputee with a prosthetic limb based on the intersegmental coordination, Transactions of the JSME (in Japanese), Vol. 81, No. 825 (2015a), DOI : 10.1299/transjsme.15-00020.

Hayashi, Y., Tsujiuchi, N., Uno, R., Makino, Y. and Tsuchiya, Y., Analysis of principal components concerning joint angles and joint moments during human gait including stairs and slopes, Transactions of the JSME (in Japanese), Vol. 81, No. 830 (2015b), DOI : 10.1299/transjsme.15-00320.

Ito, T. and Akai, M., Check point of prosthetics and orthotics (2008), pp. 14-16, Igaku-Shoin Ltd (in Japanese).

Kawamura, J., Prosthetics and orthotics (2004), pp. 14-16, Igaku-Shoin Ltd (in Japanese).

Kitamura, T., Tsujiuchi, N. and Koizumi, T., Manipulation of robot hand based on motion estimation using EMG signals, Transactions of the Japan Society of Mechanical Engineers, Series C, Vol. 73, No. 735 (2007), pp. 3024-3030 (in Japanese).

Sawamura, S., Amputation and prosthesis (2004), pp. 1-5, Ishiyaku Publishers, Inc (in Japanese).

Suzuki, S., Analytical study on control of above-knee prosthesis in swing phase, Transactions of the Japan Society of Mechanical Engineers, Series C, Vol. 70, No. 695 (2004), pp. 2110-2117 (in Japanese).

Suzuki, S., Experimental study on an active knee joint mechanism without an external energy source, Transactions of the Japan Society of Mechanical Engineers, Series C, Vol. 75, No. 756 (2009), pp. 2274-2279 (in Japanese).

Toyota, A., Yamasaki, H., Katou, M., Miyagi, S. and Yoshiba, T., The effect of difference in the practice methods on the gait skill using trial above-knee prosthesis, Rigakuryoho Kagaku, Vol. 23, No. 1 (2008), pp. 67-71 (in Japanese).

Zatsiorsky, V., The mass and inertia characteristics of the main segments of the human body, Biomechanics VIII-B (1983), pp. 1152-1159. 